\title{
Collector Efficiency by Single Pass of Solar Air Heaters with and without Using Fins
}

\author{
Foued Chabane $^{1,2, *}$, Noureddine Moummi ${ }^{1,2}$, Said Benramache ${ }^{3}$, Djamel Bensahal ${ }^{1}$, and \\ Okba Belahssen ${ }^{3}$ \\ ${ }^{1}$ Mechanics Department, Faculty of Sciences and Technology, University of Biskra, Algeria \\ 2 Mechanical Laboratory, Faculty of Sciences and Technology, University of Biskra, Algeria \\ ${ }^{3}$ Materials Science Department, Faculty of Science, University of Biskra, Algeria \\ *E-mail: fouedmeca@hotmail.fr (Corresponding author)
}

\begin{abstract}
This paper presents the study of heat transfer in a solar air heater by using new design of solar collector. The collector efficiency in a single pass of solar air heater without, and with using fins attached under the absorbing plate has been investigated experimentally. Due to adding the fins to the interior of an absorber plate, the desirable effect of increasing the heat transfer coefficient compensates for the undesirable effect of decreasing the driving force (temperature difference) of heat transfer, while the attached fins provide an enlarged heat transfer area. In this study, the absorbing plate of solar collector is attached with fins for further improved performance. The improvements of collector efficiencies in the single pass solar air heaters with, and without fins attached; increase with increasing the mass flow rate, especially for operating at lower air flow rate. Experiments were performed for two air mass flow rates of 0.012 and $0.016 \mathrm{~kg} / \mathrm{s}$. Moreover, the maximum efficiency obtained for the 0.012 and $0.016 \mathrm{~kg} / \mathrm{s}$ with, and without fins were $40.02,51.50 \%$ and $34.92,43.94 \%$ respectively. A comparison of the results of the mass flow rates by solar collector with, and without fins shows a substantial enhancement in the thermal efficiency.
\end{abstract}

Keywords: Experiment, efficiency, solar energy, fins, temperature, heat transfer, air heater.

ENGINEERING JOURNAL Volume 17 Issue 3

Received 31 December 2012

Accepted 7 April 2013

Published 1 July 2013

Online at http://www.engj.org/

DOI:10.4186/ej.2013.17.3.43 


\section{Introduction}

In the study, a test of solar collector air was performed based on the heating of air by longitudinal fins (semi-cylindrical form), and the surface area for heat exchange. Our study seeks an increase in the thermal efficiency of the solar collector, by using a single pass counter flow solar air collector with longitudinal fins. To this end, a semi-cylindrical form is one of the important and attractive design improvements that has been proposed to improve thermal performance. The paper presents an experimental analysis of a single pass solar air collector with and without fins. Experiments aim to evaluation the study of heat transfer in the thickness of a solar collector, and indicated that the heat exchange is affected by the weather condition.

Conventional solar air heaters mainly consist of panels, insulated hot air ducts and air blowers in active systems. The panel consists of an absorber plate and a transparent cover. Different factors affect the air heater efficiency such as collector dimensions, type and shape of absorber plate, glass cover, inlet temperature, wind speed and etc.

Solar air heaters can be fabricated using cheaper as well as less amount of material as compared to conventional solar air heaters. Thermal efficiency of a solar air heater is generally considered poor because of low rate of heat transfer capability between absorber plate and air flowing in the duct. In order to make a solar air heater a more effective solar energy utilization system, thermal performance needs to be improved by enhancing the heat transfer rate from absorber plate to air flowing in the duct of solar air heater. One of the methods for the enhancement of convective heat transfer is by creating turbulence at heat transfer surface with the help of artificial roughness on absorber plate.

Recently, many studies have been conducted on the efficiency and exergy analysis of a collector panel. Effect of geometrical parameters of $\mathrm{V}$-shaped ribs on heat transfer and fluid flow characteristics in rectangular duct of a solar air heater with absorber plate having V-shaped ribs was investigated by Momin $e t$ al. [1]. In other studies, different fins are soldered on the collector's back [2, 3]. In addition to the essential effects of free and forced convections $[4,5]$, considerable improvement in collector efficiency is also obtainable through an increase the transfer area and to create the turbulence inside the flow channel by using fins [4], baffles [6], or corrugated surfaces [7, 8].

Alvarez et al. [9] developed an efficient single-glass air solar collector with an absorber plate made of recyclable aluminum cans. They compared the thermal efficiency of the collector with the reported ones. An experimental investigation carried out on the performance of the offset rectangular plate fin with various glazing [10]. In this work, they are used in heat exchangers, and are experimentally studied. As the offset rectangular plate fins are mounted in staggered pattern and oriented parallel to the fluid flow, high thermal performance is obtained with low-pressure losses. A periodic analysis of a double glass, single duct solar air heater with packed bed with upward air flow was investigated by Singh et al. [11]. They used different packed bed materials such as concrete, bricks, coal, copper, aluminum, etc. They found that coal gives as good performance as metallic materials. The heater efficiency was found to be $54 \%$ when coal and copper were used and $\mathrm{m}=0,012 \mathrm{~kg} / \mathrm{s}$. Donggen Peng et al. [12], studied a novel solar air collector of pinfin integrated absorber, designed to increase the thermal efficiency. In the performance analysis of varying flow rate on PZ7-11.25 pin-fin array's collector, the correlation equation for a heat transfer coefficient is obtained and the efficiency variation vs. air flow rate is determined in this work. Chabane et al. [13] report the experimental performance of solar air heater with internal fins in the interior of an absorber plate: in the region of Biskra. The study is focused on a heat transfer in the course of the thickness of solar collector. It is found that external factors such as wind speed, and ambient temperature affect the evolution of the temperature such as the temperature of transparent cover, temperature of an absorber plate taking into account of temperature of the fluid between an absorber plate and a bottom plate, and the temperature of the exterior plate on the outside. Another work reported the effect of the mass flow rate range between 0.012 and $0.016 \mathrm{~kg} / \mathrm{s}$ on the solar collector with semi-cylindrical fins $[14,15]$. The effect of the mass flow rate in the range of 0.0078 to $0.0166 \mathrm{~kg} / \mathrm{s}$ on the solar collector with longitudinal fins was reported [16, 17]. The flat-plate solar air heater [18-22] is considered to be a simple device consisting of one (transparent) covers situated above an absorbing plate with the air flowing under absorber plate [21, 22]. The conventional flat-plate solar air heater has been investigated for heat-transfer efficiency improvement by introducing forced convection [23, 24], extended heat-transfer area [25, 26], and the increase of air turbulence [27, 28].

The present study aims to review the designed and analyzed a thermal efficiency of a solar air heater. Experiments are performed to compare a solar collector without and with using fins attached at the back the absorber plate. The efficiency of the solar air collectors depends significantly on the solar radiation, 
mass flow rate, surface geometry of the collectors, and whether fins are used at the back of the absorber plate. The efficiency of the collector improves with increasing solar intensity at a mass flow rate of 0.012 and $0.016 \mathrm{~kg} / \mathrm{s}$, due to the enhanced heat transfer to the air. The efficiency of the solar air collector is proven to be higher. The highest collector efficiency and air temperature rise were achieved by the finned collector with a tilt angle of $45^{\circ}$, whereas the lowest values were obtained from the collector without using fins.

\section{Experimental}

\subsection{Heat Transfer Coefficients}

The convective heat transfer coefficient $h$ for air flowing over the outside surface of the glass cover depends primarily on the wind velocity $\mathrm{V}_{\text {wind. }}$. McAdams [29] obtained an experimental result as:

$$
h=5.7+3.8 V_{\text {wind }}
$$

where the units of $\mathrm{h} 1 \mathrm{ac}$, out and $\mathrm{V}_{\text {wind }}$ are $\mathrm{W} / \mathrm{m}^{2} \mathrm{~K}$ and $\mathrm{m} / \mathrm{s}$, respectively. An empirical equation for the loss coefficient from the top of the solar collector to the ambient was developed by Klein [30]. The heat transfer coefficient between the absorber plate and the airstream is always a base, resulting in the low thermal efficiency of the solar panel. Increasing the absorber plate shape area will increase the heat transferred to the flowing air.

\subsection{Collector Thermal Efficiency}

The efficiency of a solar collector is defined as the ratio of the amount of useful heat collected to the total amount of radiation striking the collector surface during any period of time.

$$
\eta=\frac{\text { Solar Energy Collected }}{\text { Total Solar Striking Collector Surface }}=\frac{Q_{u}}{I \times A_{c}}
$$

Useful heat collected for an air-type solar collector can be expressed as:

$$
\begin{gathered}
Q_{u}=\dot{m} C_{p}\left(T_{\text {outlet }}-T_{\text {inlet }}\right) \\
\text { with } \dot{m}=V_{f} . S
\end{gathered}
$$

So, collector thermal efficiency becomes, basis of the energy distribution of the collector, as Fig. 10 presents, efficiency of the collector, serving as the main indicator, is calculated by Eq. (4):

$$
\eta=\dot{m} C_{p} \frac{\left(T_{\text {outlet }}-T_{\text {inlet }}\right)}{I \times A_{c}}
$$

Thermal properties of air are considered to be variables according to the follow expressions [31], where the fluid temperature is evaluated in Celsius:

$$
\begin{gathered}
C_{p}=999.2+0.1434 T_{f}+1.101 \times 10^{-4} T_{f}^{2}-6.7581 \times 10^{-8} T_{f}^{3} \\
\lambda=0.0244+0.6773 \times 10^{-4} T_{f} \\
v=0.0284 \times 10^{-4}+0.00105 \times 10^{-4} T_{f}
\end{gathered}
$$

The air density is calculated assuming the fluid as an ideal gas by the expression.

$$
\rho=353.44 / T_{f}
$$

where $T_{f}$ is the absolute air temperature. 


\section{Experimental Setup and Measurement Procedure}

A schematic view of the constructed single-flow under an absorber plate and in hollow semi cylindrical structure located under an absorber plate system of the collector is shown in Fig. 1, and photographs of two different absorber plates of the collector and the view of the absorber plate in the collector box are shown in Fig. 2(a) and (b), respectively. In this study, two types of absorber plates were used. The absorbers were made of galvanized iron sheet with black chrome selective coating. Dimension and plate thickness for two collectors were $0.5 \mathrm{~mm}$. The cover window type a Plexiglas of $3 \mathrm{~mm}$ thickness was used as glazing. Single transparent cover was used in all two collectors. Thermal losses through the collector backs are mainly due to the conduction across the insulation (thickness $4 \mathrm{~cm}$ ) and those caused by the wind and the thermal radiation of the insulation are assumed negligible. After installation, the two collectors were left operating several days under normal weather conditions for weathering processes. Thermocouples were positioned evenly, on the top surface of the absorber plates, at identical positions along the direction of flow, for both collectors. Inlet and outlet air temperatures were measured by two well insulated thermocouples. The output from the thermo-couples was recorded in degrees Celsius by means of a digital thermocouple thermometer 6802II. The ambient temperature was measured by a digital thermometer with sensor in display LCD CCTV-PM0143 placed in a special container behind the collectors' body. The total solar radiation incident on the surface of the collector was measured with a Kipp and Zonen CMP 3 Pyranometer. This meter was placed adjacent to the glazing cover, at the same plane, facing south. The measured variables were recorded at a time interval of $15 \mathrm{~min}$ and include insolation, inlet and outlet temperatures of the working fluid circulating through the collectors, ambient temperature, absorber plate temperatures at several selected locations and air flow rates (Lutron AM-4206M digital anemometer). All tests began at 9 am and ended at $4 \mathrm{pm}$.

The layout of the solar air collector studied is shown in Fig. 2. The collector served as the baseline one, with the parameters as follows:

- The solar collecting area was $2 \mathrm{~m}$ (length) $\times 1 \mathrm{~m}$ (width);

- The installation angle of the collector was $45^{\circ}$ from horizontal plane;

- The transparent cover was made of a Plexiglas panel, with a thickness of $3 \mathrm{~mm}$;

- The height of stagnant air layer was $0.02 \mathrm{~m}$;

- The absorber plate was made of galvanized, which was $0.5 \mathrm{~mm}$ thick and black paint;

- Thermal insulation boarded EPS (expanded polystyrene board), with thermal conductivity 0.037 $\mathrm{W} /(\mathrm{m} \mathrm{K})$, was put on the exterior surfaces of the back and side plates, with a thickness of $40 \mathrm{~mm}$.

- The CMP 3 Pyranometer is an instrument for measuring the solar irradiance and digital thermometer Model Number: DM6802B.

- The absorber of a plate absorption coefficient $\alpha=0.95$, the transparent cover transmittance $\tau=0.9$ and absorptive of the glass covers, $\alpha_{g}=0.05 ; 16$ Positions of thermocouple's connecter to plates and two thermocouples to outlet and inlet flow;

- Five fins under absorber plate form of semi cylindrical longitudinal was $1.84 \mathrm{~m}$ (length) $\times 0.03 \mathrm{~m}$ (Radian); the distance between two adjacent fins and fins $120 \mathrm{~mm}$, and $5 \mathrm{~mm}$ thickness.

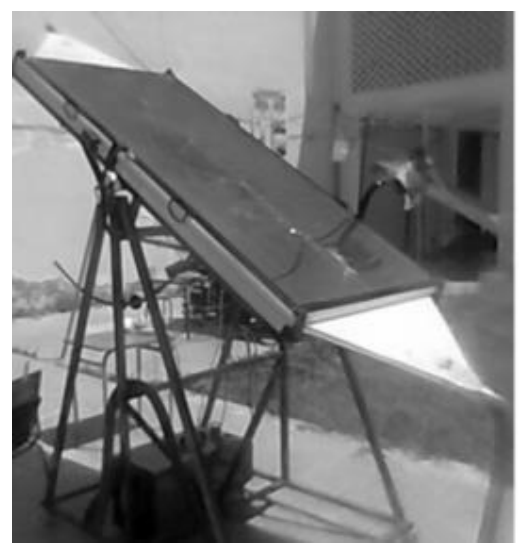

Fig. 1. The photograph of experimental setup. 


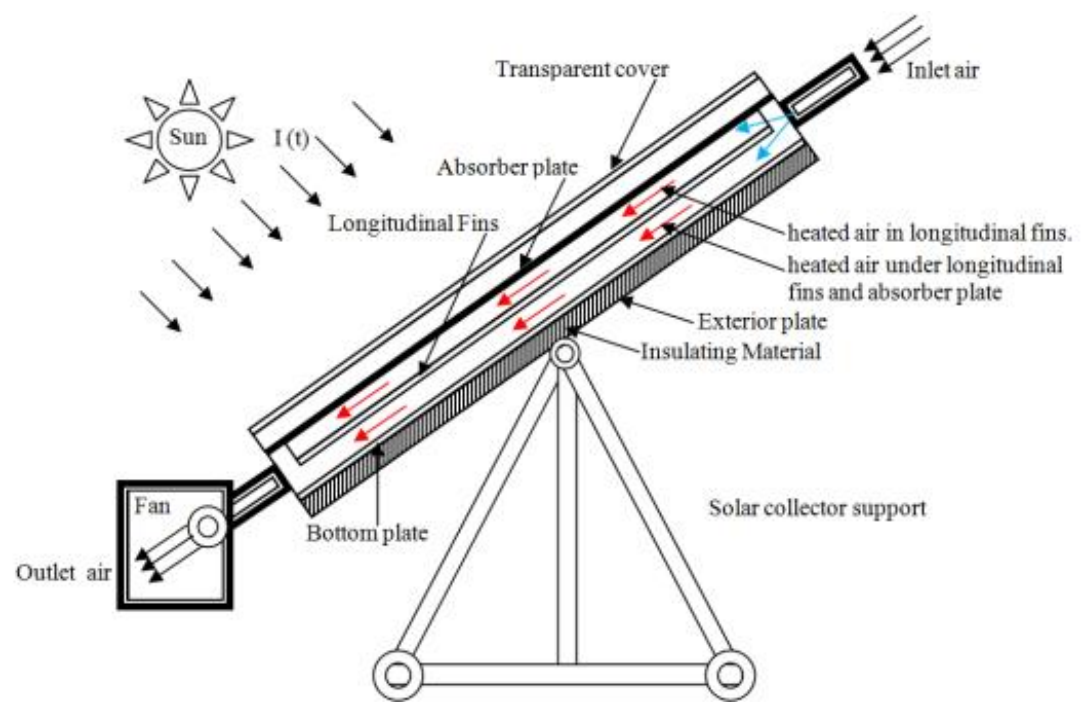

Fig. 2. Schematic views of experimental setup.

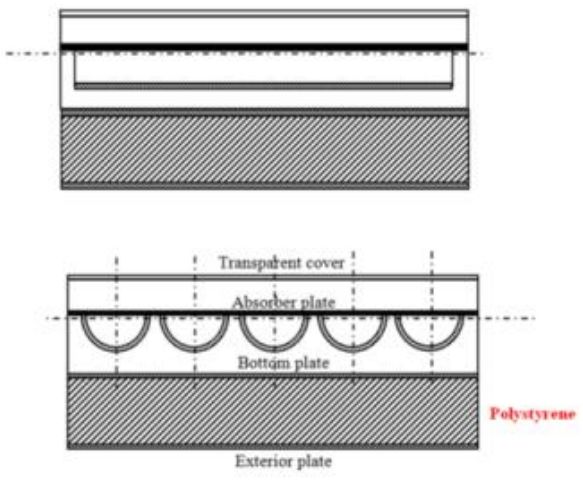

(a)
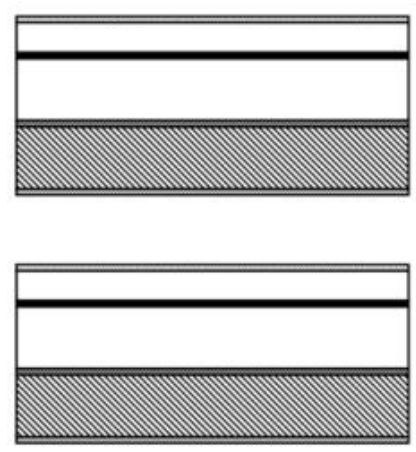

(b)

Fig. 3. Schematic views of the box solar collector.

\section{Results and Discussion}

Figure 4 shows the hourly variations of the measured solar radiation of different conditions of the days with flat-plate and using fins at the back the absorber plate, corresponding months such as January, February and May when $\mathrm{m}=0.012$ and $0.016 \mathrm{~kg} / \mathrm{s}$, respectively. The maximum values of solar radiation are 895 and $907 \mathrm{~W} / \mathrm{m}^{2}$, with flat-plate during the days between 25/01/2012 and 19/02/2012. The solar intensity in the days of 13-15/05/2012 are 757 and $762 \mathrm{~W} / \mathrm{m}^{2}$, when $\mathrm{m}=0.012$ and $0.016 \mathrm{~kg} / \mathrm{s}$, for corresponding solar collector with fins. While their daily average values are obtained as 787.5 and 803.5 $\mathrm{W} / \mathrm{m}^{2}$ for the flat-plate solar collector with fins as 673.5 and $691 \mathrm{~W} / \mathrm{m}^{2}$. The temperatures of various elements increase with time as the solar radiation increases showing their maximum values at 13:00 as seen in Figs. 5 and 6. Comparisons between the measured solar intensity of the following time of the day, are shown in Fig. 3, on 25 July 2012 and 13 May 2012 of the flat-plate and with fins, when the mass flow rate $\mathrm{m}=0.012 \mathrm{~kg} / \mathrm{s}$. The difference in solar irradiation is the same for 19 February 2012 and 15 May 2012 when $\mathrm{m}=0.016 \mathrm{~kg} / \mathrm{s}$, at a rate equal to the $145 \mathrm{~W} / \mathrm{m}^{2}$. Note that the low solar intensity in May caused the tilt angle to be kept the same for all the months. The tilt angle affects the thermal characteristics or the performance of solar air heaters $[16,17]$. 


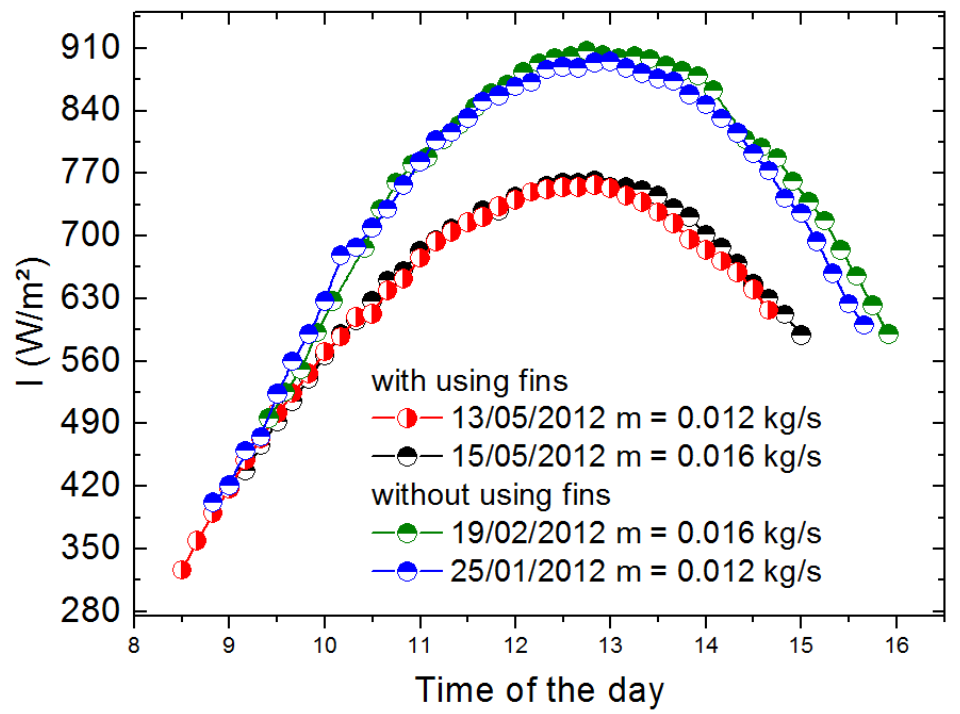

Fig. 4. Hourly variation of solar irradiation, for months of January, February and May (2012).

Figure 5 shows the temperature of the transparent cover as a function of length along the solar collector. We have four points of the measurement about the solar collector with and without using fins. We can see the evolution of the temperature transparent cover of solar collector with fins is more than the solar collector without using fins, caused by the tilt from horizontal plane, the solar intensity, and the weather conditions such as wind speed and ambient temperature. In this study, we choose a tilt angle $45^{\circ}$ and fixed in all months corresponding to the winter months of the region of Biskra city of Algeria. In the summer months the tilt angle is equal to $38^{\circ}$. But in this study we can fix the tilt angle corresponding to the winter month for solar collector without using fins, and the summer month for the solar collector with using fins.

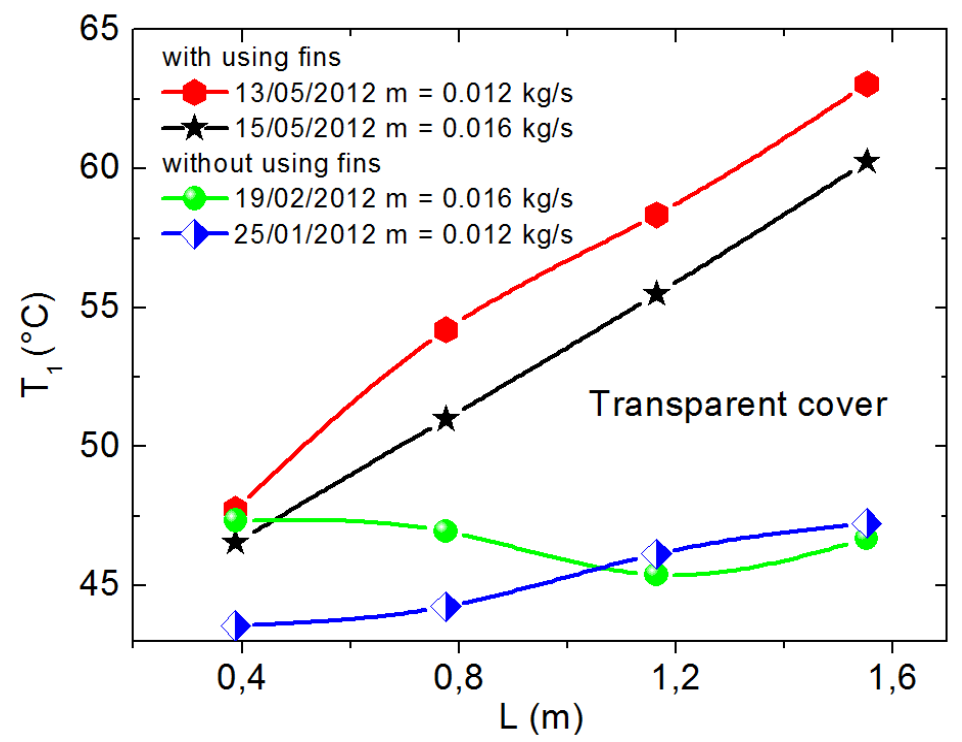

Fig. 5. Average temperature of the transparent cove with and without using fins for the months of January, February and May (2012).

The average temperatures follow the direction of length along the solar collector, i.e., $x_{i}$ were 0.388 , $0.776,1.164$ and $1.552 \mathrm{~m}$, where $\mathrm{i}=1,2,3,4$. The temperature at this point depends on the days between $13-15 / 05 / 2012$ when $\mathrm{m}=0.012$ and $0.016 \mathrm{~kg} / \mathrm{s}$, for the configuration with using fins. The average temperatures were $\mathrm{T}_{1}=47.75,54.2,58.35$ and $63.05^{\circ} \mathrm{C}$, and $\mathrm{T}_{1}=46.55,51,55.5$ and $60.25^{\circ} \mathrm{C}$, respectively 
(Table 1), were affected by the weather conditions such as wind speed $V_{\text {wind }}(1.3$ and $1.1 \mathrm{~m} / \mathrm{s})$ and ambient temperature $\left(\mathrm{T}_{\mathrm{a}}=31.75,31.6^{\circ} \mathrm{C}\right)$, for the configuration without using fins for the months of January and February, corresponding to the mass flow rates 0.012 and $0.016 \mathrm{~kg} / \mathrm{s}$. The average temperatures were $\mathrm{T}_{1}=$ $43.55,44.25,46.15$ and $47.25^{\circ} \mathrm{C}$, and $\mathrm{T}_{1}=47.35,46.95,45.4$ and $46.7^{\circ} \mathrm{C}$, respectively, as listed in Table 1 .

Table 1. Average temperature of the transparent cover corresponding to the mass flow rates of $\mathrm{m}=0.012$ and $0.016 \mathrm{~kg} / \mathrm{s}$, and the length of solar collector with and without using fins for the months of January, February and May (2012).

\begin{tabular}{|c|c|c|c|c|}
\hline \multirow{2}{*}{$x_{i}(m)$} & $0.016(\mathrm{~kg} / \mathrm{s})$ & $0.012(\mathrm{~kg} / \mathrm{s})$ & $0.016(\mathrm{~kg} / \mathrm{s})$ & $0.012(\mathrm{~kg} / \mathrm{s})$ \\
\hline & \multicolumn{2}{|c|}{$T_{1}\left(C^{\circ}\right)$} & \multicolumn{2}{|c|}{$T_{1}\left(C^{\circ}\right)$} \\
\hline 0.388 & 46.55 & 47.75 & 47.35 & 43.55 \\
\hline 0.776 & 51.00 & 54.20 & 46.95 & 44.25 \\
\hline 1.164 & 55.50 & 58.35 & 45.40 & 46.15 \\
\hline \multirow[t]{2}{*}{1.552} & 60.25 & 63.05 & 46.70 & 47.25 \\
\hline & \multicolumn{2}{|c|}{ Longitudinal fins } & & Flat-plate \\
\hline
\end{tabular}

Figure 6 shows the temperature of the absorber plate corresponding to two solar collectors without and with using fins. The temperature is a function of length of solar collector, for $\mathrm{x}_{1}=0.388 \mathrm{~m}$. The temperature of absorber plate in the days 25/01/2012 and 19/02/2012 depends on the mass flow rates of 0.012 and $0.016 \mathrm{~kg} / \mathrm{s}$ respectively, and without using fins was $\mathrm{T}_{2}=97$ and $98.5^{\circ} \mathrm{C}$ respectively, as listed in Table 2. For the collector with using fins under an absorber plate during the days of $13-15 / 05 / 2012$, corresponding to the mass flow rates of 0.012 and $0.016 \mathrm{~kg} / \mathrm{s}$, the temperature was 83 and $84{ }^{\circ} \mathrm{C}$ respectively. We can see that the difference in temperature between two configurations by rate is 14 and $14.5^{\circ} \mathrm{C}$. The variation of the temperature of the absorber plate is affected by air mass flow rates as a function of length of the solar collector. The effect of adding fins interior to the absorber plate has been shown in Table 2. The temperature was measured experimentally. It can be seen from Fig. 6 that the curves of temperature tend to increase with decreasing air mass flow rate. For a specific air mass flow rate at a constant ambient temperature, the temperature increases with increasing solar intensity. Again, it can be clearly explained that the longitudinal fins at the back of an absorber plate helps increase the outlet-air temperature. Besides the convection, the emittance of the absorber surface influences the heat transfer to the caloporting air. Ben Slama (1987) [32] measured the efficiency obtained with differently colored absorbers. The results for an air flow rate of 0.012 and $0.016 \mathrm{~kg} / \mathrm{s}$, are shown in Table 2 .

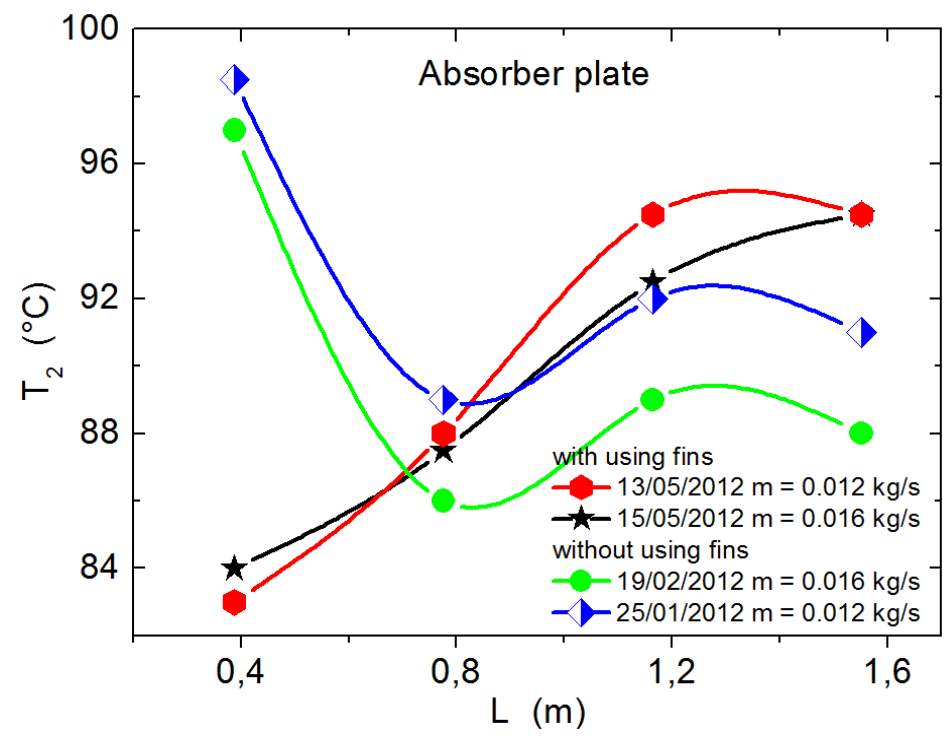

Fig. 6. Average temperature of absorber plate with and without using fins for the months of January, February and May (2012). 
Table 2. Average temperature of the absorber plate corresponding to mass flow rates of $\mathrm{m}=0.012$ and $0.016 \mathrm{~kg} / \mathrm{s}$ along the length of solar collector with and without using fins for the months of January, February and May (2012).

\begin{tabular}{|c|c|c|c|c|}
\hline \multirow{2}{*}{$x_{i}(m)$} & $0.016(\mathrm{~kg} / \mathrm{s})$ & $0.012(\mathrm{~kg} / \mathrm{s})$ & $0.016(\mathrm{~kg} / \mathrm{s})$ & $0.012(\mathrm{~kg} / \mathrm{s})$ \\
\hline & \multicolumn{2}{|c|}{$T_{2}\left(C^{\circ}\right)$} & \multicolumn{2}{|c|}{$T_{2}\left(C^{\circ}\right)$} \\
\hline 0.388 & 84.00 & 83.00 & 97.00 & 98.50 \\
\hline 0.776 & 87.50 & 88.00 & 86.00 & 89.00 \\
\hline 1.164 & 92.50 & 94.50 & 89.00 & 92.00 \\
\hline \multirow[t]{2}{*}{1.552} & 94.50 & 94.50 & 88.00 & 91.00 \\
\hline & \multicolumn{2}{|c|}{ Longitudinal fins } & \multicolumn{2}{|c|}{ Flat-plate } \\
\hline
\end{tabular}

Figure 7 shows the average temperature of the bottom plate, as a function of length along the solar collector, at $\mathrm{x}_{1}=0.388 \mathrm{~m}$, for two modes flat-plate and with fins, corresponding to two flow rates of $\mathrm{m}=$ 0.012 and $0.016 \mathrm{~kg} / \mathrm{s}, \mathrm{T}_{3}=64$ and $54^{\circ} \mathrm{C}$ respectively (Table 3). The direction is changed immediately in the second and third position of measurement by $\mathrm{T}_{3}=88$ and $82{ }^{\circ} \mathrm{C}$, and $\mathrm{T}_{3}=80$ and $69.5^{\circ} \mathrm{C}$ respectively. Table 3 shows that the flow fluid or the irradiation heat is not distributed as expected, but by solar collector with using fins under the absorber plate. We can see another thing, the temperature varied normally as function of length of solar collector. We can expect that the fluid takes the heat energy from the absorber plate and the bottom plate of a first point. The typical outlet temperature for the solar collector without using fins equal $50.9^{\circ} \mathrm{C}$ and $48.7^{\circ} \mathrm{C}$, mass flow rate of 0.012 and $0.016 \mathrm{~kg} / \mathrm{s}$, for the configuration of the solar collector with using fins under an absorber plate was 67.1 and $64.7^{\circ} \mathrm{C}$, respectively. We can see the temperature of airflow corresponding to configuration with using fins takes more heat than the mode without using fins. The type of using fins gives a considerable amount of thermal energy in the fluid.

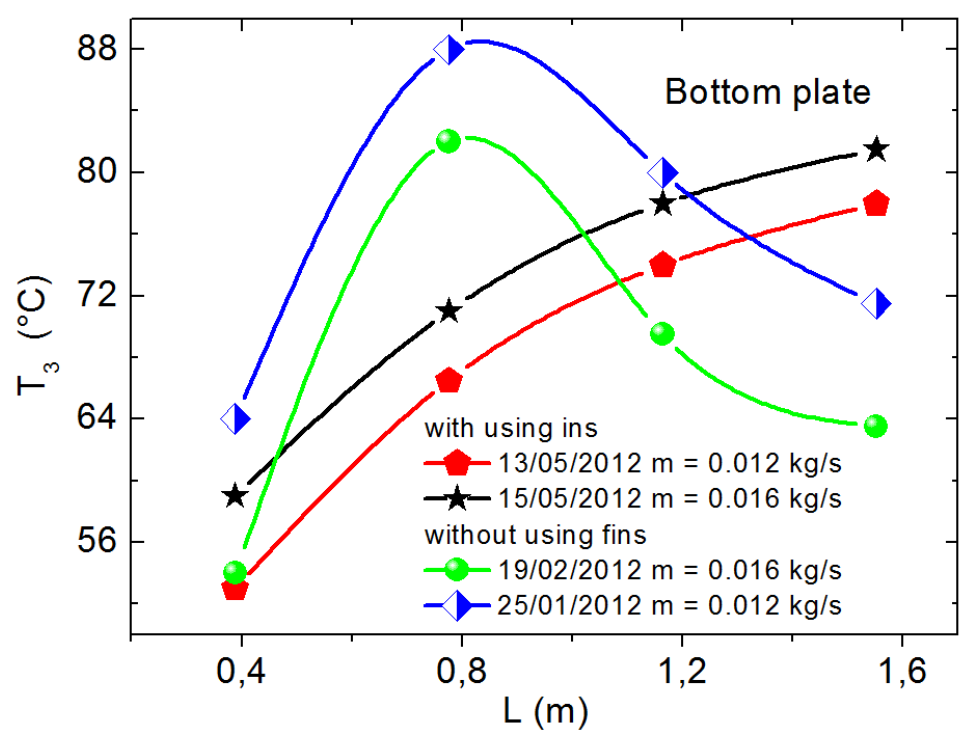

Fig. 7. Average temperature of the bottom plate with, and without using fins for months of January, February and May (2012). 
Table 3. Average temperature of the bottom plate corresponding to mass flow rates $\mathrm{m}=0.012$ and 0.016 $\mathrm{kg} / \mathrm{s}$, and length of solar collector with and without using fins for the months of January, February and May (2012).

\begin{tabular}{lcccc}
\hline & $0.016(\mathrm{~kg} / \mathrm{s})$ & $0.012(\mathrm{~kg} / \mathrm{s})$ & $0.016(\mathrm{~kg} / \mathrm{s})$ & $0.012(\mathrm{~kg} / \mathrm{s})$ \\
\cline { 2 - 5 }$x_{i}(m)$ & \multicolumn{3}{c}{$T_{3}\left(C^{\circ}\right)$} & \multicolumn{2}{c}{$T_{3}\left(C^{\circ}\right)$} \\
\cline { 2 - 5 } 0.388 & 59.00 & 53.00 & 54.00 & 64.00 \\
0.776 & 71.00 & 66.50 & 82.00 & 88.00 \\
1.164 & 78.00 & 74.00 & 69.50 & 80.00 \\
1.552 & 81.50 & 78.00 & 63.50 & 71.50 \\
\cline { 2 - 5 } & \multicolumn{3}{c}{ Longitudinal fins } \\
\hline
\end{tabular}

Figure 8 shows the temperature of the exterior plate depending on time of the day corresponding to mass flow rates for the months of January, February and May (2012). The temperature of the exterior plate is varied to standard local time of the day. The experiment carried out is presented in Fig. 8 and Table 4. In general, the starting temperature was found to be increasing linearly form of 0.4 to $1.6 \mathrm{~m}$ as a function of length of solar collector with little fluctuation during some of the days. For the configuration of the solar collector used, the temperature of the exterior plate was found to reduce with increasing air wind speed and convection heat loss coefficient due to wind. It then decreases as solar radiation drops to lower valuing later during the day for the same mass flow rate. The maximum temperature between 0.4 and $0.8 \mathrm{~m}$ is due to changing outdoor conditions.

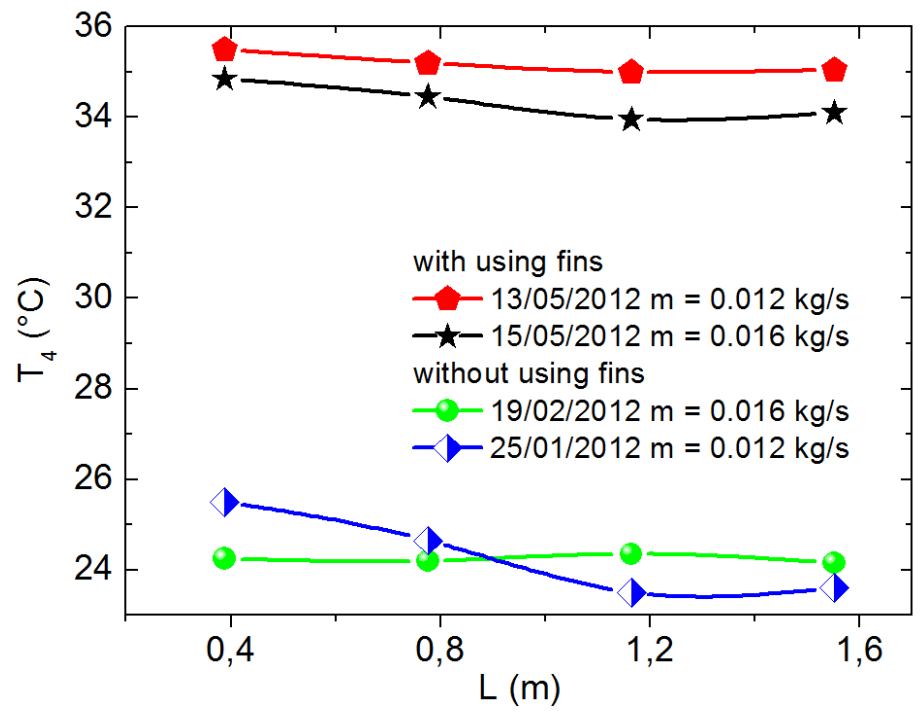

Fig. 8. Average temperature of the exterior plate with and without using fins for the months of January, February and May (2012).

Table 4 Average temperature of the exterior plate corresponding to mass flow rates $\mathrm{m}=0.012$ and 0.016 $\mathrm{kg} / \mathrm{s}$, and length of solar collector with and without using fins for the months of January, February and May (2012).

\begin{tabular}{lcccc}
\hline \multirow{3}{*}{$x_{i}(m)$} & $0.016(\mathrm{~kg} / \mathrm{s})$ & $0.012(\mathrm{~kg} / \mathrm{s})$ & $0.016(\mathrm{~kg} / \mathrm{s})$ & $0.012(\mathrm{~kg} / \mathrm{s})$ \\
\cline { 2 - 5 } 0.388 & \multicolumn{3}{c}{$T_{4}\left(C^{\circ}\right)$} & \multicolumn{3}{c}{$T_{4}\left(C^{\circ}\right)$} \\
\cline { 2 - 5 } 0.776 & 34.85 & 35.50 & 24.25 & 25.50 \\
1.164 & 34.45 & 35.20 & 24.20 & 24.65 \\
1.552 & 33.95 & 35.00 & 24.35 & 23.50 \\
\multicolumn{2}{c}{34.10} & 35.05 & 24.15 & 23.60 \\
\cline { 2 - 5 } & \multicolumn{2}{c}{ Longitudinal fins } \\
\hline
\end{tabular}


Figure 9 shows the ambient temperature as a function of time of the day, this variation depends on weather conditions. It is varied by two configurations of solar collectors. Without using fins the absolute ambient temperature corresponding to mass flow rate $\mathrm{m}=0.012$ and $0.016 \mathrm{~kg} / \mathrm{s}$ was $\mathrm{T}_{\mathrm{a}}=20$ and $18{ }^{\circ} \mathrm{C}$, and with using fins was 31.75 and $31.6^{\circ} \mathrm{C}$. The ambient temperature helped the system with heat transfer, consequently prove that the ambient temperature has an effect directly on the solar collector, and in the thermal properties. The maximum temperature is limited to two types, corresponding to the mass flow rates of 0.012 and $0.016 \mathrm{~kg} / \mathrm{s}$, were $25,21.1{ }^{\circ} \mathrm{C}$ and $39.9,39.2^{\circ} \mathrm{C}$, respectively. For the months of January, February and May, this change is enough to affect the solar collector. That is why we have made some adjustments to the solar collector to add the internal longitudinal fins under the absorber plate. The measurements were both during summer and winter seasons. The tilt angle $45^{\circ}$ is kept fixed corresponding to the winter season.

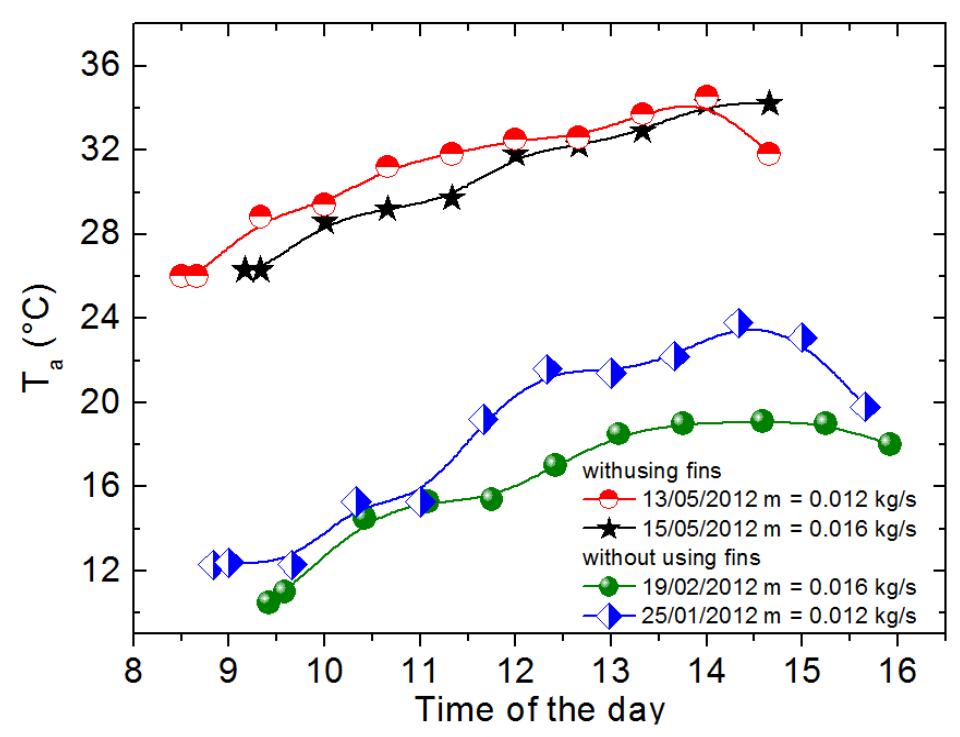

Fig. 9. Ambient temperature with and without using fins for January, February and May (2012).

In Fig. 10, we observe that the daily efficiency of the heater increases exponentially with increasing air flow rate. This can be explained by the rapid improvement of the internal thermal convective exchanges in the collector combined to the slight variation of the overall thermal losses.

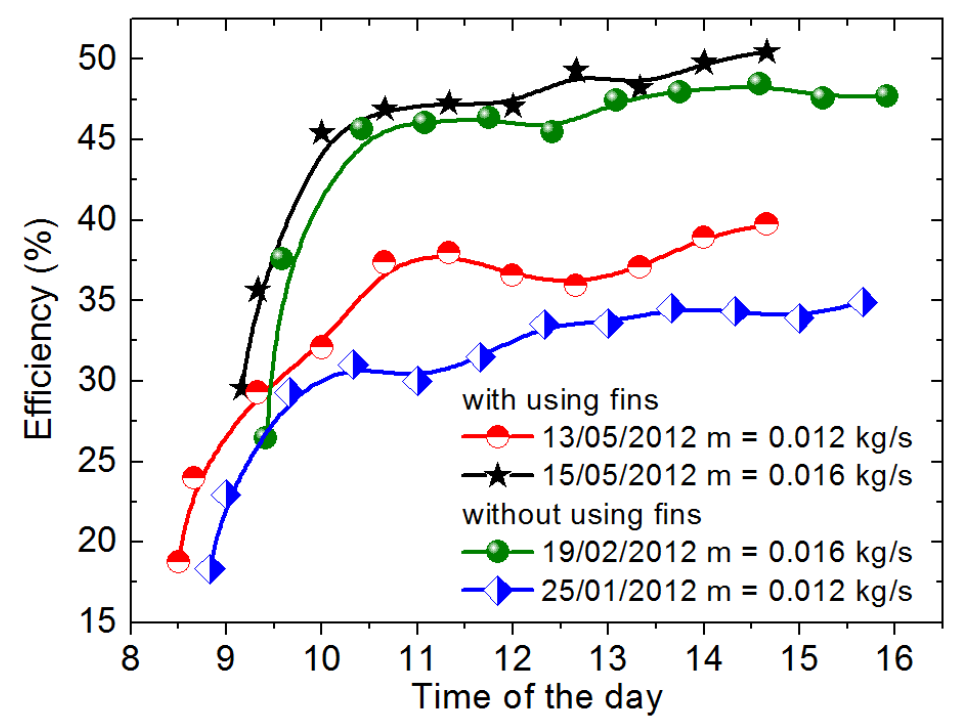

Fig. 10. Effect of the air flow on the daily efficiency of the collector, with, and without using fins for months of January, February and May (2012). 
Efficiency versus time at various air rates and for the flat-plate and with fins at the back of the absorber plate is shown in Fig. 10. The efficiencies start to increase to a maximum at 12:00 to 16:00 h. The efficiency of the mode with fins is higher than that of the flat-plate by 33-50\% depending upon the air mass flow rate. The maximum efficiencies obtained for the solar air heater without and with using fins at $\mathrm{m}=0.012$ and $0.016 \mathrm{~kg} / \mathrm{s}$ were $\eta=35.02 \%$ at $15: 20$ and $\eta=39.72 \%$ at $14: 40 \mathrm{~h}$, respectively. The thermal efficiency in both collectors was improved with increasing air mass flow. It is also clear from the results presented in Fig. 13 that the efficiency increases with the increase in mass flow rate. Aldabbagh et al [33] reported that the efficiency increases with the increase in mass flow rate and has reached $27 \%$ when the mass flow rate was equal to $\mathrm{m}=0.012 \mathrm{~kg} / \mathrm{s}$ and $42 \%$ of the flow rate equal to $\mathrm{m}=0.018 \mathrm{~kg} / \mathrm{s}$ for double pass collector's heater and the single-pass collector. He indicated that the thermal efficiency increases with increasing mass flow rate $\mathrm{m}=0.012 \mathrm{~kg} / \mathrm{s}$, and the efficiency was $\eta=39 \%$ and $\eta=36 \%$ for $\mathrm{m}=0.018 \mathrm{~kg} / \mathrm{s}$. The thermal efficiency of the heater improves with increasing air flow rates due to an enhanced heat transfer to the air flow and the temperature difference decreases at a constant tilt angle of $45^{\circ}$. Solar intensity is at their highest values at noon about 13:30 as expected. The solar intensity decreases as the time passes through the afternoon. Figure 10 shows the overall results of experiments, including the difference in air inlet and outlet temperature and daily instantaneous solar intensity levels. The ambient temperature was between 20 and $33.4^{\circ} \mathrm{C}$. The inlet temperatures of the two types of solar air collectors were measured and compared to ambient temperature. The temperature differences between the inlet and outlet temperature can be compared directly when determining the performance of the collectors. The highest daily solar radiation is obtained as 895 and $900 \mathrm{~W} \cdot \mathrm{m}^{-2}$ for a flat-plate and 753 and $755 \mathrm{~W} \cdot \mathrm{m}^{-2}$ at solar collector with fins. As expected, it increases during the morning to a peak value of 895 and $900 \mathrm{~W} \cdot \mathrm{m}^{-2}, 753$ and $755 \mathrm{~W} \cdot \mathrm{m}^{-2}$, respectively, for the solar collector without and with using fins at noon, and starts to decrease in the afternoon in all the days of experiments.

\section{Conclusion}

In this paper, the heat exchanges in a Plexiglas cover solar air heater are analyzed and an explicit expression of the temperature of the air flowing in that collector is developed as a function of the space coordinate in the flow direction and the time dependent solar intensity. Then the effects of various parameters such as the inlet air temperature, the distance between the absorber and the transparent cover and the air flow on the dynamic behavior of the collector are studied. The solar air collectors were tested and their performance was compared. The efficiency depends significantly on the mass flow rate, the solar irradiation and surface geometry of the collectors. The efficiency of the collector improves with increasing solar intensity and mass flow rate both 0.012 and $0.016 \mathrm{~kg} / \mathrm{s}$, due to enhanced heat transfer to the air flow. The condition of weather affects the mass flow rate on heat transfer. The efficiency of the solar air collector is proven to be higher. The highest collector efficiency and air temperature rise were achieved by the finned collector with an angle of $45^{\circ}$, whereas the lowest values were obtained from the collector without fins. The efficiency of the solar air collectors depends significantly on the solar radiation and surface geometry of the collectors and the fins on the back of the absorber plate account for the mass flow rate.

It is seen that the thermal efficiency increases as the mass flow rate and the temperatures of the heater elements increase until maximum values and then decrease slowly when the solar irradiation and ambient temperature decrease.

\section{Nomenclature}

$\mathrm{T}_{1} \quad$ Temperature of transparent cover $\left({ }^{\circ} \mathrm{C}\right)$

$\mathrm{T}_{2} \quad$ Temperature of absorber plate $\left({ }^{\circ} \mathrm{C}\right)$

$\mathrm{T}_{3} \quad$ Temperature of bottom plate $\left({ }^{\circ} \mathrm{C}\right)$

$\mathrm{T}_{4} \quad$ Temperature of exterior plate $\left({ }^{\circ} \mathrm{C}\right)$

$\mathrm{T}_{\text {sky }} \quad$ Temperature of sky $\left({ }^{\circ} \mathrm{C}\right)$

$\mathrm{T}_{\mathrm{a}} \quad$ Ambient temperature $\left({ }^{\circ} \mathrm{C}\right)$

$\mathrm{x}_{\mathrm{i}} \quad$ Local direction longitudinal of points $(\mathrm{m})$

$\mathrm{y}_{\mathrm{i}} \quad$ Local direction of thickness panel (m)

$\mathrm{T}_{\text {in }} \quad$ Temperature inlet $\left({ }^{\circ} \mathrm{C}\right)$

$\mathrm{T}_{\text {out }} \quad$ Outlet fluid temperature $\left({ }^{\circ} \mathrm{C}\right)$ 
$\mathrm{V}_{\text {wind }}$ Wind velocity $(\mathrm{m} / \mathrm{s})$

$\mathrm{h}_{\mathrm{w}} \quad$ Convection heat transfer coefficient $\left(\mathrm{W} / \mathrm{m}^{2} \mathrm{~K}\right)$

Cp Specific heat of air $(\mathrm{J} / \mathrm{kg} \mathrm{K})$

Ac Area of absorber plate surface $\left(\mathrm{m}^{2}\right)$

i Position of thermocouple connected of 1 to 4.

$\Delta \mathrm{T} \quad$ Temperature difference $\left({ }^{\circ} \mathrm{C}\right)$

$\mathrm{T}_{\mathrm{f}} \quad$ The absolute air temperature $\left({ }^{\circ} \mathrm{C}\right)$.

@ Density of air $\left(\mathrm{kg} / \mathrm{m}^{3}\right)$

Greek Symbols

$\eta \quad$ Collector efficiency (\%)

I Global irradiance incident on solar air heater collector $\left(\mathrm{W} / \mathrm{m}^{2}\right)$

$m \quad$ Air mass flow rate $(\mathrm{kg} / \mathrm{s})$

$\varepsilon \quad$ Emissivity of absorber plate

$\alpha_{a} \quad$ Absorber plate absorption coefficient

$\tau \quad$ Transparent cover transmittance

$\alpha_{g} \quad$ Absorptive of the glass covers

$\nu \quad$ Kinematic viscosity $\left(\mathrm{m}^{2} / \mathrm{s}\right)$

$\lambda \quad$ Thermal conductivity $(\mathrm{W} / \mathrm{m} \mathrm{K})$

\section{References}

[1] A. M. E. Momin, J. S Saini, and S. C Solanki, "Heat transfer and friction in solar air heater duct with Vshaped rib roughness on absorber plate," International Journal of Heat and Mass Transfer, vol. 45, pp. 33833396, 2002.

[2] A. Hachemi, "Experimental study of heat transfer and fluid flow friction in solar heater with and without selective absorber," Renewable Energy, vol. 17, pp. 155-168, 1999.

[3] N. S. Thakur, J. S. Saini, and S. C. Solanki, "Heat transfer and friction factor correlations for packed bed solar air heater for a low porosity system," Solar Energy, vol. 74, pp. 319-329, 2003.

[4] H. M. Yeh, and Y. C. Ting, "Effects of free convection on collector efficiencies of solar air heaters," Applied Energy, vol. 22, pp. 145-155, 1986.

[5] H. M. Yeh, and T. T. Lin, "The effect of collector aspect ratio on the collector efficiency of flat-plate solar air heaters," Energy, vol. 20, pp. 1041-1047, 1995.

[6] H. M. Yeh, C. D. Ho, and C. Y. Lin, "Effect of collector aspect ratio on the collector efficiency of upward type baffled solar air heaters," Energy Conversation and Management, vol. 41, pp. 971-981, 2000.

[7] L. Goldstein, and E. M. Sparrow, "Experiments on transfer characteristics of a corrugated fin and tube heat-exchanger configuration," ASME Journal of Heat Transfer, vol. 98, pp. 26-34, 1976.

[8] W. Gao, W. Lin, T. Liu, and C. Xia, "Analytical and experimental studies on the thermal performance of cross-corrugated and flat-plate solar air heaters," Applied Energy, vol. 84, pp. 425-541, 2007.

[9] G. Alvarez, J. Arce, L. Lira, and M. R. Heras, "Thermal performance of an air solar collector with an absorber plate made of recyclable aluminum cans," Solar Energy, vol. 77, pp. 107-113, 2004.

[10] A. Hachemi, "Experimental study of thermal performance of offset rectangular plate fin absorberplates," Renewable Energy, vol. 17, pp. 371-384, 1999.

[11] D. Singh, S. S. Bharadwaj, and N. K. Bansal, "Thermal performance of a matrix air heater," Energy Research, vol. 6, pp. 103-110, 1982.

[12] D. Peng, X. Zhang, H. Dong, and K. Lv, "Performance study of a novel solar air collector," Applied Thermal Engineering, vol. 30, pp. 2594-2601, 2010.

[13] F. Chabane, N. Moummi, and S. Benramache, "Experimental performance of solar air heater with internal fins inferior an absorber plate: In the region of Biskra," International Journal of Energy and Technology, vol. 4, pp. 1-6, 2012.

[14] F. Chabane, N. Moummi, and S. Benramache, "Performances of a single pass solar air collector with longitudinal fins inferior an absorber plate," American Journal of Advanced Scientific Research, vol. 1, no. 4, pp. 146-157, 2012. 
[15] F. Chabane, N. Moummi, and S. Benramache, "Experimental study on heat transfer for a solar air heater and contribution the fins to improve the thermal efficiency," International Journal of Advanced Renewable Energy Research, vol. 1, no. 9, pp. 487-494, 2012.

[16] F. Chabane, N. Moummi, S. Benramache, and A. S. Tolba, "Experimental study of heat transfer and an effect the tilt angle with variation of the mass flow rates on the solar air heater," Int. J. Sci. Eng. Inves., vol. 1, pp. 61-65, 2012.

[17] F. Chabane, N. Moummi, and S. Benramache, "Effect of the tilt angle of natural convection in a solar collector with internal longitudinal fins," Int. J. Sci. Eng. Inves., vol. 1, pp. 13-17, 2012.

[18] D. J. Close, and R. V. Dunkle, "Behaviour of adsorbent energy storage beds," Sol. Energy, vol. 18, pp. 287-292, 1976.

[19] C. H. Liu, and E. M. Sparrow, "Convective-radiative interaction a parallel plate channel-application to air-operated solar collectors," Int. J. Heat Mass Transf., vol. 23, 1137-1146, 1980.

[20] M. K. Seluck, and A. A. M. Sayigh, Solar Air Heaters and Their Applications, New York, Academic 269 Press, 1977.

[21] H. M. Tan, and W. W. S. Charters, "Experimental investigation of forced-convective heat transfer for fully developed turbulent flow in a rectangular duct with asymmetric heating," Solar Energy, vol. 13, pp. 121-125, 1970.

[22] A. Whillier, "Plastic covers for solar collectors," Solar Energy, vol. 7, pp. 148-151, 1963.

[23] J. A. Duffie, and W. A. Beckman, Solar Engineering of Thermal Processes 3rd ed., Wiley, New York, 1980.

[24] J. K. Tonui, and Y. Tripanagnostopoulos, "Improved PV/T solar collectors with heat extraction by forced or natural air circulation," Renewable Energy, vol. 32, pp. 623-637, 2007.

[25] W. Gao, W. Lin, T. Liu, and C. Xia, "Analytical and experimental studies on the thermal performance of cross-corrugated and flat-plate solar air heaters," Appl. Energy, vol. 84, pp. 425-441, 2007.

[26] A. A. Mohamad, "High efficiency solar air heater," Solar Energy, vol. 60, pp. 71-76, 1997.

[27] S. K. Verma, and B. N. Prasad, "Investigation for the optimal thermohydraulic performance of artificially roughened solar air heaters," Renewable Energy, vol. 20, pp. 19-36, 2000.

[28] H. M. Yeh, “Theory of baffled solar air heaters," Energy, vol. 17, pp. 697-702, 1992.

[29] W. H. McAdams, Heat Transmission, McGraw-Hill, New York, 1954.

[30] S. A. Klein, "Calculation of flat-plate loss coefficients," Solar Energy, vol. 17, pp. 79-80, 1975.

[31] G. N. Tiwari, Solar Energy: Fundamentals, Design Modeling and Applications, CRC Press and Narosa Publishing House, New York and New Delhi, 2002.

[32] R. B. Slama, "Contribution to the study and the development of pumps and solar air collectors," Thesis of Specialty in Energetic, University of Valenciennes, France, 1987.

[33] L. B. Y. Aldabbagh, F. Egelioglu, and M. Ilkan, "Single and double pass solar air heaters with wire mesh as packing bed,” Energy, vol. 5, pp. 3783-3787, 2010. 